удк 332.142

\title{
ШЕРІНГ-ТЕХНОЛОГІЯ В ОСВІТІ ЯК ІНСТРУМЕНТ СТРАТЕГІЧНОГО УПРАВЛІННЯ РОЗВИТКОМ ЕКОНОМІКИ
}

\author{
SHARING TECHNOLOGY IN EDUCATION \\ AS A TOOL OF STRATEGIC ECONOMIC \\ DEVELOPMENT MANAGEMENT
}

\author{
Чекан Ірина Василівна \\ аспірантка, \\ ДВНЗ «Ужгородський національний університет» \\ ORCID: https://orcid.org/0000-0003-2701-8350 \\ Chekan Iryna \\ Uzhhorod National University
}

\begin{abstract}
Ускладнення економічної, політичної та соціальної ситуації в Україні пояснює необхідність пошуку нових шляхів розвитку та важелів, серед яких особливе місце займає стратегічний менеджмент. Метою дослідження $€$ обґрунтування доцільності використання спільних технологій освіти у процесі стратегічного управління економічним розвитком. В статті представлене авторське бачення стратегічного управління з позиції його контенту, значимості та ролі в процесі розвитку людини. Описано вплив людського ресурсу на досягнення стратегічних цілій та доведена необхідність постійного оновлення компетенцій через навчання протягом життя. Висвітлені шерінгові технології в освіті і запропоновано створення регіонально-корпоративного університету, якій виконує фрункції майдану, де зустрічається наука з практикою і вирішуються проблеми мікро- та мезо-рівнів.

Ключові слова: економіка обміну, освіта, стратегічний менеджмент, людський розвиток, регіональнокорпоративний університет.

Усложнение экономической, политической и социальной ситуации в Украине объясняет необходимость поиска новых путей развития и рычагов, среди которых особое место занимает стратегический менеджмент. Целью исследования является обоснование целесообразности использования общих технологий образования в процессе стратегического управления экономическим развитием. В статье представлено авторское видение стратегического управления с позиции его контента, значимости и роли в процессе развития человека. Описано влияние человеческого ресурса на достижение стратегических целей и доказана необходимость постоянного обновления компетенций через обучение в течение жизни. Представлены шеринговые технологии в образовании и предложено создание регионально-корпоративного университета, выполняющего функции площадки, где встречается наука с практикой и решаются проблемы микро- и мезо-уровней.
\end{abstract}

Ключевые слова: экономика обмена, образование, стратегический менеджмент, развитие человека, регионально-корпоративный университет.

The complication of the economic, political and social situation in Ukraine explains the need to search for new ways of development and levers that ensure the effectiveness of its management. Among such tools, strategic management occupies a special place. The purpose of the study is to substantiate the feasibility of using sharing technologies of education in the process of strategic management of economic development. Strategic management of economic systems is advisable to represent in the form of a complex phenomenon because of the essence, its value and role of an intellectual conductor in the process of civilizational transformations. The main subsystem of strategic management is human resources. The human resource, acting as the initial condition for effective management, must meet the requirements: 1 . Be highly educated and professionally fit at a certain point in time. 2 . Due to the fact that each moment of development differs from the previous one (according to the concept of VUKA), human resources, in order to be adequate to the requirements of each moment, must constantly develop and learn. Sharing technologies in education are realized through interaction: S2S - student share knowledge with the other student; B2S - business without prior knowledge to the student; S2B - students in the process of continuing to share results in business; R2S - region for providing information to students; S2R - students to share information, results in the region; $\mathrm{B} 2 \mathrm{R}$ - business development with the region, allowing the region to transmit information about the possibility 
and contamination of business activities in the region; R2B - the region is to bring to the business the problems of meso-level and enterprises to the social broadcasting. Regional-corporate university is the sharing science-organizing and resource technology collection of information, researching regional and business problems; training and retraining of professional, as well as being aware of the regional situation and ecosystem, good news and transmission of possible strategic challengers. Human resources must have the competence necessary for activity in the minds of VUCA-economy.

Keywords: sharing economy, education, strategic management, human development, regional-corporate university.

Постановка проблеми. Посилення конкуренції на всіх рівнях економіки - від гравців глобального світу до нано-суб'єктів - викликає необхідність пошуку шляхів отримання додаткових сил розвитку та способів ці сили використати ефективно. У такий спосіб $\epsilon$ стратегічне управління, фундаментом якого $€$ людський ресурс та його постійне оновлення у якісному плані. Освіта $€$ умовою, яка потрібна на вирішення стратегічним управлінням його основних завдань.

Сучасні економічні інструменти дозволяють вирішувати стратегічні завдання ефрективнішим способом, наприклад, використовуючи шеринг. Переваги можливостей шерингу підкреслено експертами Британської Ради, які стверджують, що «підприємства також зрозуміли прибутковість економіки спільного використання та прагнуть отримати вигоду від використання цих недостатньо використаних ресурсів» [1]. Науковці розглядають шерінг як економіку та як бізнес-модель, тобто певну ділову технологію. Незважаючи на конкретне наповнення шерінгу, його значення підкреслено Asta Daunarience, Aura Drakšaite, Vytautas Snieškac, Gitana Valodkienơ наступним чином: «Концепція спільного використання зобов'язує організації шукати інноваційні рішення сьогодні, думаючи про проблеми завтрашнього дня». [2] Це підтверджує думку про стратегічні можливості шерінгу, в тому числі й в освіті.

Аналіз останніх досліджень та публікацій. Доцільність пошуку нових шляхів реалізації стратегічних завдань, необхідність людського розвитку підкреслена Kubiniy N. Ta iн., які вважають, що саме «людський потенціал відіграє вирішальну функцію у регіональному стратегічному розвитку, забезпечує якісне фрункціонування всіх складових організаційноекономічного потенціалу» [5]. Honcharenko I. та ін. визначають доцільність коректності оцінки органів влади для забезпечення місцевого стратегічного розвитку [3]. 3 позиції необхідності фрормування потенціалу безпеки для успішного стратегічного розвитку економіки розглядають проблематику енергетичних компаній M. Kryshtanovych та інші [4].
Шерінг як економіка та технологія також знаходиться на піке уваги дослідників та практиків. Leung, X. Та ін. вважають, що «економіку спільного використання можна розглядати як екосистему, в якій організми співіснують і взаємодіють один з одним у динамічному середовищі» [6]. Ієрархичний устрій шерінгової економіки представлено Xusen Cheng та ін. наступним чином: «Екосистема спільної економіки охоплює три різні рівні розгляду та відносин між основними сторонами: національний, рівень організацій та індивідуальний рівень» [7]. Asta Daunarience та ін. доводять, що «економіка спільного використання - це план майбутньої бізнесідеї, який пояснює, як поєднати економічні, екологічні та соціальні проблеми» [2]. Разом 3 тим, проблеми шерінгу в освіті, яка фрормує людський фрактор стратегічного розвитку, в дослідженнях сучасних економістів не знайшов належної уваги.

Ціллю дослідження $€$ обґрунтування доцільності застосування шерінгових технологій освіти в процесі стратегічного управління економічним розвитком. Для досягнення мети вирішені наступні завдання. Розкрита сутність стратегічного управління розвитком економіки. Визначена якість людських ресурсів, необхідні для стратегічного управління. Показано місце шерінгових технологій в освіті. Обґрунтовано доцільність створення регіонально-корпоративних університетів.

Результати дослідження. Стратегічне управління економічними системами доцільно у вигляді складного явища, як А) за суттю; Б) за значенням і В) як ролі у процесі цивілізаційних перетворень (рис. 1).

Для більш точної експозиції вказаних позицій стратегічного управління зупинимося кожної 3 них.

А. Змістовний контент та організаційний фреймінг стратегічного управління націлені на досягнення системою переваг, які радикально відрізняють ії від інших, надаючи потенціалу такі сили, які зумовлюють випереджальний розвиток. Такими конкурентними перевагами є людські ресурси, які здатні виконувати завдання просунутого рівня. 


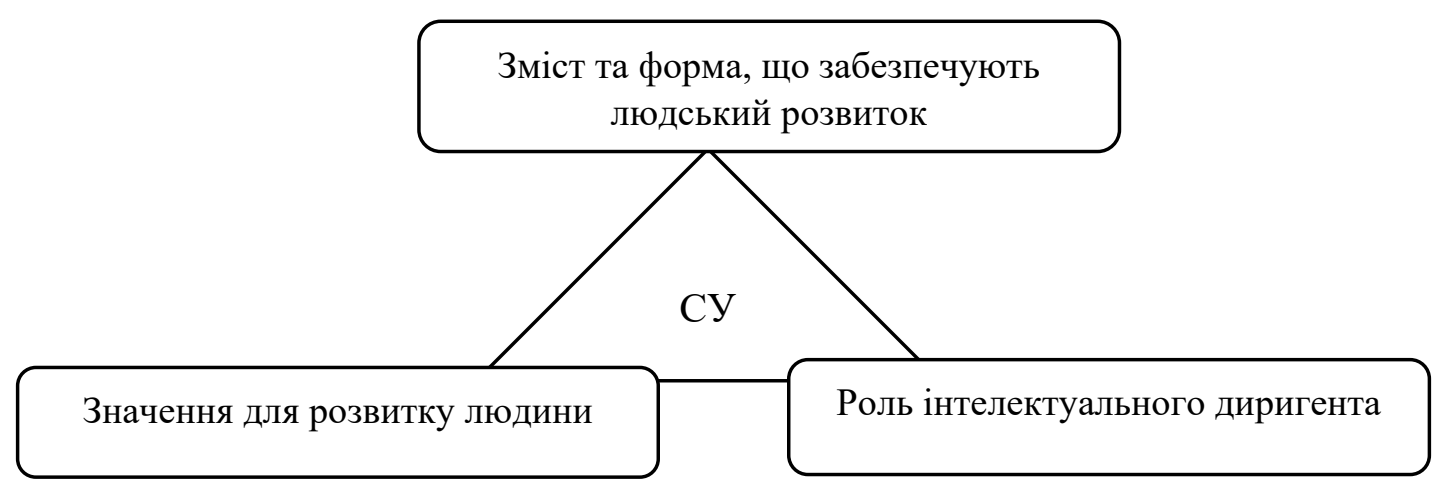

Рис. 1. Стратегічне управління (СУ) як інструмент людського розвитку

Джерело:складено автором

Б. Значення стратегічного управління проявляється у наступному:

- підвищення ефективності функціонування економічної системи;

- оптимальне використання ресурсів;

- в умовах високих техногенних ризиків, боротьби транснаціональних корпорацій за надприбутки, кліматичних змін стратегічне управління на перше місце має ставити екологічну безпеку дій економіко-виробничої системи.

В) Роль стратегічного управління полягає у досягненні навмисного, наперед визначеного стану економічної системи. При цьому економіка $€$ елементом цивілізаційної системи як сукупності матеріально-технічних та духовних досягнень, здобутих у певному історичному періоді. Тому, тобто можна сказати, що стратегічне управління грає роль інтелектуального диригента цивілізаційних перетворень.

Усі три складові стратегічного управління (контент, значення та роль) визначаються наявністю людського ресурсу, для якого та за допомогою якого стратегічно заплановані перетворення необхідно здійснити.

Вступаючи в систему стратегічного управління, людський ресурс перетворюється на визначальну СУ підсистему і стає фрактором. На виході людський ресурс набуває додаткових, нових якостей. Визначення даних додаткових якостей і $є$ основним завданням стратегічного управління. У рамках цього дослідження основною додатковою якістю визначено нові компетенції, отримані в результаті освіти. Людський ресурс, виступаючи вихідною умовою для результативного управління, має бути адекватним вимогам стратегічного управління:

- має бути високоосвіченим на певний момент. У зв'язку з тим, що кожен момент розвитку відрізняється від попереднього (за концепцією VUCA), людський ресурс для того, щоб бути адекватним вимогам кожного моменту, має постійно розвиватись та навчатися.

- Кожен новий момент приносить нові можливості для розвитку та навчання, нові технології. Це означає, що професіонал має вміти вчитися та робити це протягом усієї кар'єри.

Такими технологіями можна назвати організаційну - це регіонально-корпоративний університет - та ресурсну - шерінг.

В освіті шерінг використовується протягом усієї його історії. Так, користування бібліотечними ресурсами - це шерінг, слухання лекції викладача - також шерінг.

Для розвитку регіональної економіки та отримання стратегічних конкурентних переваг організаційні та ресурсні технології можуть бути агреговані у вигляді шерінгових ресурсів. Крім цього, нові технології «охопили значну кількість працівників фрорм нетрадиційної зайнятості - аутстафрфінг, аутплейсмент, позикова праця, тимчасова зайнятість, дистанційна зайнятість, смартстафрфінг, неповна зайнятість, самозайнятість, тимчасова, дистанційна зайнятість, фрріланс та ін. - це не що інше як шеринг у трудовій сорері.... Шерінг у сучасній освіті розпочався 3 появи численних сайтів із пошуку репетиторів для школярів. Далі почалося бурхливе зростання пропозицій на ринку онлайн-освіти. Гібридне навчання, що поєднує онлайн-і офрлайнформи, запровадила Udacity» [8].

В межах регіонально-корпоративного університету шерінг-освіта реалізується через взаємодію: S2S - студент ділиться знаннями 3 іншим студентом (захист курсових та дипломних робіт, доповіді на семінарах, конференціях); B2S - бізнес безпосередньо надає знання студенту (більшою мірою практичного характеру); S2B - студенти в процесі досліджень діляться результатами з бізнесом (аналіз діяльності підприємства в курсових 
та дипломних роботах, в результаті проходження практики); R2S - регіон надає інсрормацію студентам (через зустрічі 3 обласним керівництвом, лекції практиків регіонального рівня); S2R - студенти діляться інфрормацією, результатами дослідження з представниками регіонального управління (результати наукових досліджень); B2R - бізнес на університетській площадці зустрічається з регіоном, що дозволяє передати регіону інсрормацію про можливості та загрози підприємницької діяльності в регіоні; R2B - регіон доносить до бізнесу проблематику мезо-рівня й залучає підприємства до спільного вирішення.

В даному шерінговому співвідношенні центральне місце займає майдан перетинання інфрормації та інтересів, які організаційно отримують фрорму регіонально-корпоративного університету. Регіонально-корпоративний університет $€$ шерінговою науково-організаційною технологією збору інфрормації, дослідження та обґрунтування шляхів вирішення регіональних та ділових проблем; підготовки та перепідготовки срахівців, що обізнані з регіональною ситуацією та екосистемою, здібні вирішувати існуючи та передбачати можливі стратегічні виклики; мають компетенції, необхідні для роботи в умовах ВУКА-економіки.

Іншими словами, регіонально-корпоративний університет виконує фрункції: виступає центром регіональних досліджень, в тому числі на мікрорівні, в яких прийматиме участь студенти. Це надає можливість відстежити регіональну проблематику і надати студентам навички науково-дослідної роботи; забезпечує підготовку кадрів, компетенції яких дозволяють приймати рішення та реалізовувати їх втілення в практику; сприяє впровадженню ефрективної інтенціальної економіки, яка за твердженням Кубіній Н.Ю. є найбільш ефрек- тивною платсрормою розвитку [9]; виступати в якості площадки, на якої зустрічається бізнес і регіональна влада і формується бачення майбутнього розвитку регіональної економіки.

Висновки. Ускладнення економічної, політичної та соціальної ситуації в Україні пояснює необхідність пошуку нових шляхів розвитку та важелів, які забезпечують ефрективність управління ним. Серед таких інструментів особливе місце посідає стратегічне керування.

Стратегічне управління економічними системами доцільно у вигляді складного явища, як а) за суттю; б) за значенням; в) за роллю. Людський ресурс, виступаючи вихідною умовою результативного управління, повинен відповідати вимогам: бути високоосвіченим та постійно розвиватися.

Шерінгові технології в освіті реалізуються через взаємодію: S2S - студент ділитися знаннями 3 іншим студентом; B2S - бізнес безпосередньо надає знання студенту; S2B - студенти в процесі досліджень діляться результатами з бізнесом; R2S - регіон надає інорормацію студентам; S2R - студенти діляться інформацією, результатами з регіоном; B2R - бізнес зустрічається 3 регіоном, що дозволяє передати регіону інорормацію про можливості та загрози підприємницької діяльності в регіоні; R2B - регіон доносити до бізнесу проблематику мезо-рівня та залучає підприємства до спільного вирішення.

Регіонально-корпоративний університет $\epsilon$ шерінговою науково-організаційною та ресурсною технологією збору й наукової обробки інформації та надання навчальних послуг.

В подальших дослідженнях заплановано визначити принципи шерінгової економіки та механізм їх реалізації в процесі стратегічного управління.

\section{СПИСОК ВИКОРИСТАНИХ ДЖЕРЕЛ:}

1. British Council. URL: https://learnenglish.britishcouncil.org/skills/reading/upper-intermediate-b2/the-sharingeconomy

2. Daunarience A., Drakšaite A., Snieškac V., Valodkienơ G. Evaluating Sustainability of Sharing Economy Business Models. 20th International Scientific Conference «Economics and Management». 2015. 836-841. URL: https://www.sciencedirect.com/science/article/pii/S1877042815058413

3. Honcharenko, I., Dubinina, M., Kubiniy, N., \& Honcharenko, O. Evaluation of the regional public authorities' activities. Management Theory and Studies for Rural Business and Infrastructure Development. 2021. 43(1). 90-99. URL: https://ejournals.vdu.lt/index.php/mtsrbid/article/view/2026

4. Kryshtanovych M., Akimova L., Akimov O., Kubiniy N., Marhitich V. Modeling the Process of Forming the Safety Potential of Engineering Enterprises. International Journal of Safety and Security Engineering. 2021. 11(3). 223-230. URL: http://iieta.org/journals/ijsse

5. Kubiniy N., Marhitich V., Kosovilka T. Potential of strategic development of regional economy. Challaenges in Globalizationn in Economic and Business. Proceedings of the 4th International Scientific Conference. Tbilisi 
University. Georgia. 1-2 November, 2019. p. 237-242. URL: https://dspace.tsu.ge/handle/123456789/523?localeattribute=en

6. Leung, X. Y., Xue, L., \& Wen, H. Framing the sharing economy: Toward a sustainable ecosystem. Tourism Managemen. 2019. 71. 44-53.

7. Xusen Cheng, Jian Mou \& Xiangbin Yan. Sharing economy enabled digital platforms for development. Information Technology for Development. 2021. 27:4. 635-644. DOI: https://doi.org/10.1080/02681102.2021.1971831

8. Бирженюк Г.М., Ефиморва Т.В. Шеринг как новый ориентир образования. Инновационное развитие профрессионального образования. 2020. № 2(26). С. 12-21.

9. Кубиний Н.Ю. Философский бекгроунд вероятности как категории интенциальной экономики. Науковий вісник Ужгородського університету. Серія Економіка. 2021. № 1(57). С. 48-53.

\section{REFERENCE:}

1. British Council. Retrieved from: https://learnenglish.britishcouncil.org/skills/reading/upper-intermediate-b2/ the-sharing-economy

2. Daunarience A., Drakšaite A., Snieškac V., Valodkienơ G. (2015) Evaluating Sustainability of Sharing Economy Business Models. 20th International Scientific Conference «Economics and Management», 836-841. Retrieved from: https://www.sciencedirect.com/science/article/pii/S1877042815058413

3. Honcharenko, I., Dubinina, M., Kubiniy, N., \& Honcharenko, O. (2021) Evaluation of the regional public authorities' activities. Management Theory and Studies for Rural Business and Infrastructure Development, 43(1), 90-99. Retrieved from: https://ejournals.vdu.lt/index.php/mtsrbid/article/view/2026

4. Kryshtanovych M., Akimova L., Akimov O., Kubiniy N., Marhitich V. (2021) Modeling the Process of Forming the Safety Potential of Engineering Enterprises. International Journal of Safety and Security Engineering, 11(3), 223-230. Retrieved from: http://iieta.org/journals/ijsse

5. Kubiniy N., Marhitich V., Kosovilka T. Potential of strategic development of regional economy. Challaenges in Globalizationn in Economic and Business. Proceedings of the 4th International Scientific Conference. Tbilisi University. Georgia. 1-2 November, 2019. P. 237-242. Retrieved from: https://dspace.tsu.ge/handle/123456789/523? locale-attribute $=$ en

6. Leung, X. Y., Xue, L., \& Wen, H. (2019) Framing the sharing economy: Toward a sustainable ecosystem. Tourism Managemen, 71, 44-53.

7. Xusen Cheng, Jian Mou \& Xiangbin Yan (2021) Sharing economy enabled digital platforms for development. Information Technology for Development, 27:4. 635-644. DOI: https://doi.org/10.1080/02681102.2021.1971831

8. Birzhenyuk G.M., Efimorva T.V. (2020) Shering kak novyy oriyentir obrazovaniya [Schering as a new landmark in education]. Innovatsionnoye razvitiye professional'nogo obrazovaniya, 2(26), 12-21. (in Russian)

9. Kubiniy N. (2021) Philosophical background of likelihood as a category of intentional economy [Philosophical background of probability as a category of intentional economy]. Visnyk Uzhhorodskoho Universitety, 57, 48-53. (in Russian) 